\title{
Vernon Bogdanor: Beyond Brexit: Towards a British Constitution
}

\author{
London: I.B. Tauris, 2019, xii + 285 pp, $£ 20$ hardback, \\ ISBN: 9781788316798
}

\section{Gary Wilson ${ }^{1}$}

Published online: 17 April 2020

(c) The Author(s) 2020

The subject of Brexit has received considerable attention on the part of academics of various disciplines, as attempts are made to make sense of what it is likely to mean in terms of its effects on the politics, economy, society and legal system of the United Kingdom. One area to have received, perhaps, less substantive treatment than might have been expected is that of Brexit's constitutional effects for the UK. This new book by Vernon Bogdanor is therefore particularly welcome. Bogdanor is one of the country's foremost constitutional scholars, a prolific writer on all things constitutional, and his perspectives on the constitutional dimensions of Brexit are likely to be of interest to all working in the areas of constitutional law and politics, as well as more general readers who are likely to find this book's style engaging and accessible.

The central argument of the book appears to be that Brexit has exposed or exacerbated tensions lying at the very heart of the British constitution, potentially calling for the implementation of wide-ranging constitutional reform. Noting that the doctrine of parliamentary sovereignty - which permits Parliament to enact or repeal legislative changes at will-may act as a barrier to lasting constitutional reform, Bogdanor raises the possibility that the problems raised by Brexit may only be capable of resolution following a radical constitutional overhaul which could necessitate a move towards the adoption of a "written" constitution.

The book is organised around a number of constitutional issues which have gained greater currency as a result of the UK's membership of the European and/or its recent withdrawal. These include the doctrine of parliamentary sovereignty, the status of referenda, the convention of collective ministerial responsibility, the protection of human rights, and devolution. The first chapter provides important context to the discussion contained in those which follow relating to particular constitutional

Gary Wilson

G.Wilson@ljmu.ac.uk

1 Liverpool John Moores University, Liverpool, UK 
themes, by detailing the background to the UK's entry into the European Community in 1973 and drawing out the extent to which initial national attitudes towards the European project have informed domestic developments since. The divisive nature of the European issue is also touched upon, with reference to its impact on the unity of the major political parties and the transformation of electoral behaviour, highlighted by the surge of the UK Independence Party from the 1990s onwards.

Chapters two and three are concerned respectively with mechanisms of representative and direct democracy. In the case of the former, the influence of EU membership on parliamentary sovereignty is traced through the jurisprudence of both the European Court of Justice and the UK's domestic courts. It is insightful to note that while the ECJ had developed the doctrine of the supremacy of European law-which effectively held that European law will take precedence over conflicting domestic law-even before the UK joined the EC, this was conveniently overlooked or minimised in official assessments of the impact of membership prior to entry. Any misconception as to the genuine impact of EU membership was shattered, however, following the Factortame cases where it was unambiguously ruled that domestic legal provisions at odds with measures of EU law must be set aside in deference to the European provisions. There has been ever since a degree of political desire to restore to Parliament the sovereignty it was perceived as having lost, with measures such as the 2011 European Union Act seeking to limit future transfers of legislative powers from the UK to the EU. The ultimate stage in this process was, of course, the outcome of the 2016 referendum when a narrow majority of the electorate were won over by the Leave campaign's pledge to "take back control," restoring parliamentary sovereignty to its earlier status by leaving the EU.

Referendums historically had no place in the UK's constitutional debates and were rejected by most politicians as "unconstitutional" in nature. Although Parliament may sanction the holding of referendums, they can only ever be advisory and cannot bind this sovereign body. The 1975 referendum on the UK's membership of the EC marked the first nationwide referendum, but, while held for pragmatic and tactical reasons, set in stall a process whereby this mechanism would be used to obtain public consent for various constitutional changes since, including devolution, electoral reform, Scottish independence, and culminating in the 2016 EU Membership referendum. 2016's events marked a notable first, however, in delivering an outcome at odds with the views of most MPs, who then took upon themselves the "obligation" to give effect to the verdict reached by the electorate.

The convention of collective ministerial responsibility, considered in chapter four, has been affected considerably by the European issue. Due to the divisive nature of the issue, the convention was suspended during the 1975 referendum to permit cabinet members to campaign for either side of the debate. With the exception of the Coalition government's agreed programme, which allowed for the convention to be set aside on five specific issues on which the two participating parties had some strong differences of opinion, the UK's membership of the EC/EU has been unique in it's effects on intra-party unity and the 2016 referendum campaign saw a repeat of 1975 when collective ministerial responsibility was again suspended for the duration of the campaign, allowing prominent government figures to campaign against the official government position of supporting a Remain vote. 
The extent to which the UK's protection of human rights has been influenced by its EU membership is often overlooked, but its significance is clearly explained in chapter five. Although the Human Rights Act 1998 incorporated the European Convention on Human Rights into domestic law, the Act did not undermine the doctrine of parliamentary sovereignty, and Parliament remained free to legislate in violation of Convention rights or remove their protection. Furthermore, no court can override offending primary legislation. However, the European Charter of Fundamental Rights offers stronger protection than the Human Rights Act as it forms part of EU law and, as such, its provisions must take precedence over any offending domestic legal provisions. The courts have therefore been able to use the Charter to disapply domestic provisions that conflict with key human rights norms. As the Charter will not be retained post-Brexit, human rights become dependent on the willingness of the UK's sovereign parliament for their continued protection. The future protection of human rights in the UK becomes entangled with debates over the most appropriate model for such rights to be recognised, a "British Bill of Rights" having been advocated as an improvement upon the Human Rights Act for some time by the Conservative Party. Bogdanor considers some possible mechanisms for human rights protection, touching upon the prospects of both legislative and judicial entrenchment as routes towards stronger protection.

Consideration of the impact of Brexit on devolution within the UK, the subject matter of chapter six, is highly speculative. However, it is nonetheless clear to see how developments in this respect stand to be dramatically influenced by Brexit. The different outcomes in the UK's constituent parts in the 2016 referendum, in which both Scotland and Northern Ireland registered majorities to remain within the EU, serves to reinforce the geographically divisive nature of Brexit. There is undoubtedly some feeling that Brexit strengthens the cause of Scottish independence and support for Irish reunification, dissecting the UK in the process. At the very least, there are likely to be strains upon the current devolution settlement, which might require steps to be taken to strengthen current arrangements, in turn leading to increased pressure for the adoption of a codified UK constitution which clearly allocates and demarcates powers and functions between the UK's constituent parts.

Bogdanor uses the final chapter to draw together the various strands of thinking explored and developed throughout the book to convey a picture of a United Kingdom which sits very much at a constitutional crossroads. He notes that we find ourselves in a very different world to 1972, and the act of Brexit cannot simply return the UK to the position which it was in before joining the EC. He observes that there has been much constitutional reform in the intervening four decades and that Brexit in fact strengthens the case for codification of the UK's constitutional arrangements. Two arguments are convincingly made for such a course of action, stemming from the current uncertainty of our constitutional norms, and the "nakedness" exposed by Brexit of our constitution, which offers no protection to British citizens. Some of the key issues which any process of codification will need to grapple with, as far as Bogdanor is concerned, involve determining the role and scope of referenda within the UK, reaching agreement on what rights ought to be constitutionally protected and how this should be achieved, and setting out a clear constitutional relationship between the Westminster Parliament and the UK's devolved institutions. 
This book should be read by anyone wanting to make sense of the possibilities of constitutional reform in the aftermath of Brexit. Bogdanor does not purport to have the answers to the future constitutional direction of the UK, but he effectively identifies some of the most pertinent constitutional effects of Brexit and in so doing is able to ask the kinds of questions which need to form the basis of understanding what the UK's constitutional arrangements may, and should, look like post-Brexit.

Open Access This article is licensed under a Creative Commons Attribution 4.0 International License, which permits use, sharing, adaptation, distribution and reproduction in any medium or format, as long as you give appropriate credit to the original author(s) and the source, provide a link to the Creative Commons licence, and indicate if changes were made. The images or other third party material in this article are included in the article's Creative Commons licence, unless indicated otherwise in a credit line to the material. If material is not included in the article's Creative Commons licence and your intended use is not permitted by statutory regulation or exceeds the permitted use, you will need to obtain permission directly from the copyright holder. To view a copy of this licence, visit http://creativecommons.org/licen ses/by/4.0/.

Publisher's Note Springer Nature remains neutral with regard to jurisdictional claims in published maps and institutional affiliations. 